\section{Neuroimaging Findings in Congenital Zika Syndrome}

\author{
(D)A. Poretti and DT.A.G.M. Huisman
}

S ince the early 2015 outbreak of the Zika virus, an arbovirus originally identified in Africa and Asia-Pacific and transmitted by Aedes aegypti mosquitoes, the virus has spread rapidly from Pernambuco State throughout Brazil and the Americas. In Brazil, more than 30,000 clinical cases have been reported so far. ${ }^{1}$ While the total number of infected individuals is unknown, it is expected to reach more than 1 million in the next year. ${ }^{2}$ In addition, the virus has been disseminated outside Brazil, and cases of Zika virus infection have been reported in 25 countries in the Americas, Africa, and Asia. The outbreak of Zika virus infection in Brazil was associated with an increase in congenital microcephaly by a factor of $20 .^{2}$ The suspected causal relationship between prenatal Zika virus infection and microcephaly has now been confirmed. ${ }^{3}$ This confirmation was evidenced by several observations, including the following: 1) Zika virus infection during prenatal development at times that were consistent with the defects observed; 2) a specific, rare phenotype involving microcephaly and associated brain anomalies in fetuses or infants with presumed or confirmed congenital Zika virus infection, and 3) data that strongly support the biologic plausibility, including the identification of Zika virus in the brain tissue of affected fetuses and infants. ${ }^{3-5}$ In addition, Zika virus infection has been associated with approximately 50 cases of Guillain-Barré syndrome, ${ }^{2}$ suggesting that the disease is less benign than initially thought, making Zika a "public health emergency of international concern." In 2016, more than 700 scientific articles have been published on the Zika virus. Rarely before have scientists tackled a new research topic with such a sense of urgency. Finally, the major global impact of Zika virus has been shown by various discussions about the need to delay or relocate the 2016 Rio de Janeiro Olympic Games because of public health concerns over the risk of Zika virus infection for the Olympic community.

For neuroradiologists, a detailed knowledge of the potential neuroimaging findings in children with congenital Zika syndrome is needed to accurately make the diagnosis. Head CT studies have revealed intracranial calcifications in most patients with microcephaly. ${ }^{6-8}$ Calcifications are typically located at the corticomedullary junction and involve mostly the frontal and parietal lobes. In about half of patients, calcifications may be seen in the basal ganglia and/or thalami, while calcifications within the periventricular white matter are less common. Calcifications within the cerebellum, brain stem, and spinal cord have been reported in only a few patients. ${ }^{6,7}$ The calcifications are typically punctuate, but in some patients, they may be linear or bandlike (particularly at the corticomedullary junction) or coarse (especially within the basal ganglia and thalami). In addition, head CT studies showed cortical hypogyration in all patients. ${ }^{6-8}$ Cortical

http://dx.doi.org/10.3174/ajnr.A4924 hypogyration is typically severe (with only the Sylvian fissure obviously present) and can be better delineated with MR imaging. In children who underwent MR imaging, the main cortical abnormality included a simplified gyral pattern (normal cortical thickness) associated with areas of polymicrogyria or pachygyria (thick cortex) predominantly located in the frontal lobes. ${ }^{6}$ In a few children, hemimegalencephaly and periventricular heterotopia have been reported. ${ }^{6}$ Ventriculomegaly is an additional consistent finding seen on head CT and brain MR imaging studies. ${ }^{6-8}$ Ventriculomegaly is usually moderate or severe, may involve the whole ventricular system or only the lateral ventricles with predominant enlargement of the trigones and posterior horns, and is most likely secondary to the thin cortical mantle and decreased white matter volume. An enlargement of the subarachnoid spaces is seen in most patients. ${ }^{6,8}$ On head CT, diffusely abnormal hypodensity of the white matter is seen in most infants. ${ }^{7}$ MR imaging studies revealed that the white matter hypodensity seen on CT represents, most likely, areas of dysmyelination or delayed myelination with secondary thinning of the corpus callosum. ${ }^{6,8}$ Posterior fossa involvement may include global or unilateral cerebellar hypoplasia, brain stem hypoplasia, and mega-cisterna magna in some patients. ${ }^{6-8}$ Finally, enlargement of the choroid plexus and intraventricular septations have also been reported in select patients. ${ }^{8}$ Most of these findings (particularly intracranial calcifications and ventriculomegaly) may be detected prenatally by fetal sonography from 19 weeks of gestation. ${ }^{4,9,10}$ Fetal MR imaging may provide additional information about cortical abnormalities and posterior fossa involvement. ${ }^{10}$

Abnormal cortical development and global cerebellar hypoplasia suggest an underlying disruptive pathomechanism caused by congenital Zika virus infection. Recently, experimental studies have shed more light on the neuropathogenesis of the congenital Zika virus syndrome and support a disruptive pathogenesis. In experimental models, Zika virus was shown to target human brain cells, reducing their viability and growth. ${ }^{11-13}$ These results suggest that Zika virus abrogates neurogenesis during human brain development. In addition, Zika virus infection causes a downregulation of genes involved in cell cycle pathways, dysregulation of cell proliferation, and upregulation of genes involved in apoptotic pathways, resulting in cell death. ${ }^{12}$

In congenital Zika syndrome, the skull is also affected and has a pointed occiput with overriding bones mainly in the frontal and occipital regions. ${ }^{8,14}$ The skull deformity seems to be secondary to the extensive brain abnormalities, but a primary involvement of the skull bones is not excluded. Ongoing studies should solve this hypothesis.

Many questions about Zika virus infection and congenital Zika syndrome need to be answered. For some of these open questions (eg, the most susceptible period of the fetus to the Zika virus infection, the risk and incidence of fetal microcephaly when the mother is infected with Zika virus, and the risk of developing motor and intellectual disabilities from brain abnormalities due to Zika virus infection), neuroimaging may be of great help in providing the answers and in better understanding the congenital Zika syndrome. 


\section{REFERENCES}

1. Faria NR, Azevedo Rdo S, Kraemer MU, et al. Zika virus in the Americas: early epidemiological and genetic findings. Science 2016; 352:345-49 CrossRef Medline

2. Araujo AQ, Silva MT, Araujo AP. Zika virus-associated neurological disorders: a review. Brain 2016 Jun 29. [Epub ahead of print] Medline

3. Rasmussen SA, Jamieson DJ, Honein MA, et al. Zika virus and birth defects: reviewing the evidence for causality. N Engl J Med 2016;374: 1981-87 CrossRef Medline

4. Mlakar J, Korva M, Tul N, et al. Zika virus associated with microcephaly. N Engl J Med 2016;374:951-58 CrossRef Medline

5. Calvet G, Aguiar RS, Melo AS, et al. Detection and sequencing of Zika virus from amniotic fluid of fetuses with microcephaly in Brazil: a case study. Lancet Infect Dis 2016;16:653-60 CrossRef Medline

6. de Fatima Vasco Aragao M, van der Linden V, Brainer-Lima AM, et al. Clinical features and neuroimaging (CT and MRI) findings in presumed Zika virus related congenital infection and microcephaly: retrospective case series study. BMJ 2016;353:11901 CrossRef Medline

7. Hazin AN, Poretti A, Turchi Martelli CM, et al. Computed tomographic findings in microcephaly associated with Zika virus. $N$ Engl J Med 2016;374:2193-95 CrossRef Medline
8. Cavalheiro S, Lopez A, Serra S, et al. Microcephaly and Zika virus: neonatal neuroradiological aspects. Childs Nerv Syst 2016;32: 1057-60 CrossRef Medline

9. Oliveira Melo AS, Malinger G, Ximenes R, et al. Zika virus intrauterine infection causes fetal brain abnormality and microcephaly: tip of the iceberg? Ultrasound Obstet Gynecol 2016;47:6-7 CrossRef Medline

10. Driggers RW, Ho CY, Korhonen EM, et al. Zika virus infection with prolonged maternal viremia and fetal brain abnormalities. $N$ Engl J Med 2016;374:2142-51 CrossRef Medline

11. Garcez PP, Loiola EC, Madeiro da Costa R, et al. Zika virus impairs growth in human neurospheres and brain organoids. Science 2016; 352:816-18 CrossRef Medline

12. Tang H, Hammack C, Ogden SC, et al. Zika virus infects human cortical neural progenitors and attenuates their growth. Cell Stem Cell 2016;18:587-90 CrossRef Medline

13. Qian X, Nguyen HN, Song MM, et al. Brain-region-specific organoids using mini-bioreactors for modeling ZIKV exposure. Cell 2016;165:1238-54 CrossRef Medline

14. Dain Gandelman Horovitz D, da Silva Pone MV, Moura Pone S, et al. Cranial bone collapse in microcephalic infants prenatally exposed to Zika virus infection. Neurology 2016;87:118-19 CrossRef Medline 